[Article copies available for a fee from The Transformative Studies Institute. E-mail address: journal@transformativestudies.org Website: http://www.transformativestudies.org (02011 by The Transformative Studies Institute. All rights reserved.]

\title{
Introduction \\ Kill It to Save It: How American Common Sense is Killing Us
}

\author{
Corey Dolgon ${ }^{1}$
}

In the late 1990s, Czech public officials discussed the possibility of steep new taxes on cigarettes. Inspired by studies that showed how much money went to pay the public health costs of smokers, the debate soon turned to those who advocated an outright ban on smoking. Eventually, the Czech government did outlaw all cigarette use in an effort to save billions of health care dollars as well as improve the overall health of its citizenry.

The Philip Morris Company (which changed its name to Altria Group, Inc. in 2003 to 'hide' from negative publicity), the largest exporter of tobacco cigarettes to Eastern Europe, had heard about the Czech deliberations and discussed their own need to respond. A ban on tobacco products would not only mean millions of dollars in lost sales, but a policy like this could catch on with other Eastern European countries who faced similar rising health care costs caused in part by smoking-related illnesses. The cigarette maker faced a serious economic threat and something had to be done. Besides, the economic logic seemed flawed to Phillip Morris corporate execs.

Philip Morris commissioned Arthur D. Little International Inc. to study smoking's actual cost to the public coffers. Their findings: "Based on up-to-date reliable data and consideration of all relevant contributing factors, the effect of smoking on the public finance balance in the Czech Republic in 1999 was positive, estimated at $+5,815$ million CZK," or just over $\$ 300,000,000$ a year. The study continued:

\footnotetext{
${ }^{1}$ Corey Dolgon, Ph.D., Assistant Editor of Theory in Action, is Director of Community based Learning and professor of sociology at Stonehill College; e-mail: cdolgon@stonehill.edu.
} 


\section{Corey Dolgon}

Public finance saved between 943 mil. CZK and 1,193 mil. CZK (realistic estimate: 1,193 mil. CZK) from reduced health-care costs, savings on pensions and housing costs for the elderly -- all related to the early mortality of smokers. Among the positive effects, excise tax, VAT [Value Added Tax] and health care cost savings due to early mortality are the most important.

In other words...well, you don't need other words. It's pretty plain to see that Philip Morris, along with their "objective" corporate, costbenefit researchers from Arthur D. Little could argue effectively that it was in the economic best interests of the Czech Republic to not only lift its ban on smoking, but, by logical extrapolation, encourage more people to smoke more cigarettes. Kill it to save it.

While the Philip Morris-Arthur D. Little study was roundly denounced by anti-tobacco activists and public officials on both sides of the Atlantic, the premise of the logic was not so easily dismissed. In fact, the belief that government or corporate bottom lines should drive public policies continues as paradigmatic in almost all serious debate about social issues in the United States. And if the economic outcomes (or costbenefit calculations) weren't limiting enough as a baseline for policy decisions, you can blend into the ideological cloud an uncritical and unqualified commitment to the unrestrained accumulation of wealth. The result is a seriously flawed way of thinking about and acting on public policies designed to protect and improve the general welfare. In fact, we, as Americans, don't even focus on the general public welfare as a goal. Instead, we protect and improve the ability for individuals and corporations to make profits - the rest be damned.

We pass food defamation laws prohibiting the critique of an increasingly unnatural and unhealthy food system, ${ }^{2}$ yet we refuse to adequately regulate campaign donations because, in the words of Senator Mitch McConnell, "money is speech." We dismantle pretrial release programs that in county after county successfully reduced overcrowded jails, kept people working, families together, and saved cash-strapped communities millions of dollars. Why? Because the bail bonds industry spent even more millions to protect their profits. We removed a provision for free insulin to diabetes sufferers from the 2010 health care overhaul because of lobbying by the prosthetics industry - they benefit from poor preven-

\footnotetext{
${ }^{2}$ DJ Benderman and SM Christensen. "Of Banana Bills and Veggie Hate Crimes: The Constitutionality of Agricultural Disparagement Statutes. Harvard Journal on Legislation, 135 (1997); LD Gould, "Mad Cows, Offended Emus and Old Eggs: Perihable Product Disparagement Laws and Free Speech.” Washington Law Review 1019 (1998).
} 
tive care that results in diabetes patients losing arms and legs. These are all examples of kill it to save it.

The phrase kill it to save it goes back at least as far as the Vietnam War. The American military's "pacification strategy" targeted small villages rumored to be sympathetic towards the North Vietnamese National Liberation Front. The U.S. terrorized these communities with random acts of violence and destruction, often burning homes and common areas to the ground. The most famous of these attacks resulted in the My Lai Massacre. But, according to journalist Richard Boyle, in Flower of the Dragon:

My Lai was not the act of one man. It was not the act of one platoon or one company. It was the result of an ordered and well-conducted campaign conceived at high command levels to teach a lesson to the villagers of Quang Ngai Province. The killing, of course, is part of a definite political strategy usually described as the 'pacification' of Vietnamese villagers. ${ }^{3}$

Continued murder, torture, and burning of villages forced tens of thousands of Vietnamese to become refugees, often crowded into small hamlets that could be easily watched or decimated again. As a policy, the American military was prepared to destroy Vietnam and its people to save it from Communism. Kill it to save it.

Most recently we have witnessed the shooting of a United States Congresswoman and murder of her supporters by a mentally ill man using a $9 \mathrm{~mm}$ Glock 19 semi-automatic weapon with a high capacity ammunition clip. While the extent of his illness, political opinions, etc. have yet to be determined, his carnage raises two sets of important issues relevant for understanding how a "Kill it to Save It" common sense not only pervades our culture and policy-making, but is ultimately an extremely dangerous mindset for making laws and shaping our culture. And it's literally killing us!

First, immediately following the shooting, pundits began a heated debate about the role that heightened political rhetoric (especially the kind of violent, gun-related metaphors that Sarah Palin had brandished) may have had in influencing the shooter, Jared Loughner. But little focus has been given to either the current state of mental health care in the United States or the ridiculously easy access to violent assault weapons whose only function is to kill humans. It's one of those perfectly American iro-

\footnotetext{
${ }^{3}$ Richard Boyle, Flower of the Dragon.
} 


\section{Corey Dolgon}

nies - tens of millions of Americans cannot obtain mental health care, while many mentally ill people can obtain guns.

If the NRA and their supporters are correct in saying that guns don't kill people, people do, one might think it best to be extremely careful, erring on the side of caution, in prohibiting some people to have them. The only federal restrictions that hinder gun purchases are: age (over 18); conviction for violent crime, domestic violence, or other felony; involuntary commitment to a mental institution or court determined mental incompetence; dishonorable discharge from the military; those who have renounced their American citizenship; fugitives; or drug addicts. While some states require licenses or permits, others like Alaska and Vermont don't. In perhaps the worst of all ironies Arizona recently legalized the carrying of concealed firearms and other weapons without a permit at the same time that they cut back state Medicaid coverage leaving thousands of previously diagnosed mentally ill residents without mental health care.

Second, regardless of any one politician's or pundit's violent rhetoric, and regardless of Loughner's actual political opinions and affiliations, one of the major targets of the "kill it to save it" mentality has been government itself. While Republicans long ran against "big government" or "too much government", it was Ronald Reagan's 1980 campaign that solidified a kind of common sense about evil government liberalism and incompetence. He proclaimed too many taxes were going to too many programs that were too corrupt and gave too many handouts to too many undeserving people. Although most of his morality tales were never based on facts (the welfare queens he depicted were never found, for example) his policies and rhetoric fashioned a powerful sensibility that "government wasn't the solution, government was the problem."

Bush further emphasized this in his efforts to dismantle everything from public education, food stamps and the EPA to Medicaid and Medicare. But Bush's major target was the big daddy of them all, social security. As Nobel Prize Economist, Paul Krugman, suggested, "privatizing" social security was mostly a euphemism for killing it. Many of Bush's domestic policy architects, such as Stephen Moore, of the Cato Institute, believed that: "Social Security is the soft underbelly of the welfare state,...If you can jab your spear through that, you can undermine the whole welfare state." Arguing that only the private sector could provide economic security, quality health care, education, etc., Bush called for massive deregulation as a strategy for improving all domestic policies, not just financial ones. End government spending in all areas of government (except defense and corporate subsidies) and deregulate the private sector to empower their takeover of social welfare programs. 
The strategy was an utter failure. Increasingly privatized health care not only left more and more millions of Americans without health insurance, but the coverage most people did have cost more and covered less. The privatized school choice movement-so alluring in the 1990s and early 2000s - has lost some of its steam as charter schools have failed at significant rates and private companies like Edison (in Philadelphia and San Francisco) and Mosaica (in Detroit) have been kicked out by dissatisfied school boards. But the biggest deregulatory flop has been in the financial industry itself, leading to the worst economic crisis since the Great Depression. The crisis was so bad that even Bush was forced to use government to bail out the industry - not the kind of move antigovernment activists envisioned when Bush was elected.

But the anti-government rhetoric only intensified with Obama's campaign. As Bush's failed strategies at home and abroad doomed Republicans in the 2006 and 2008 elections, they ratcheted up the paranoid and mean-spirited spewing even more. By the time Obama had won, the country's economy was so bad little could be done in the short run to stave off serious recession, unemployment, etc. Despite being in office a short time, Republicans ramped up the anti-government rhetoric and blamed Obama for everything! Meanwhile, Obama's biography allowed the anti-government rhetoric to revive a variety of age-old, tried and true forms of ideological hatred. Obama was Black and his race alone stoked the still burning fires of white supremacy. Obama was a foreigner and a Muslim (neither of which is true but why let the facts stand in the way of constructing a good anti-talisman). And, as he initiated policies suggesting that government should play a role in improving the general welfare (improving health coverage, addressing climate change, regulating Wall Street banditry) Republicans tagged him as a Communist, Socialist and a "tax-and-spend liberal" (as if these were all the same thing). By the time the Tea Party took shape in the summer of 2009, it didn't take much to get a crowd of angry people all lathered up in fear of and hatred for a Black Muslim Socialist Terrorist President.

The angry vitriol against Obama eventually seeped down to other, primarily Democrat Party officials. While the cesspool of rhetorical violence out of the mouths of Rush Limbaugh, Glenn Beck, Michael Savage, Bill O'Reilly, Sarah Palin, and many others created a cultural legitimacy for such hatred, threats and harassment against congresspersons and senators increased as well. Threats against congressmen and women rose over 300 percent in the first months of 2010 and dozens of congressional offices were vandalized after the historic March vote to overhaul health care policy. Regardless of Loughner's political affiliations or ide- 


\section{Corey Dolgon}

ology (if any), his act occurred at a particular political moment where the idea of killing government (and by extrapolation its officials) in order to save America (or "take it back" as Tea Partiers would contend) doesn't seem so farfetched. Kill it to save it!

Only strong, progressive social movements for economic and social equality will create the kinds of fundamental changes needed to rectify our "kill it to save it" common sense. But as we prepare the cultural and political ground game for such organizing, we must take a page from Gramsci's playbook and counter such destructive common sense with what he called "good sense." Unlike common sense which is "incoherent and fragmentary" but can easily be marshaled to support the status quo power of hegemony," good sense requires a "critical conception" of hegemony and a consciousness of class "for-itself." In other words, good sense would inform the cultural mainstream with the critical tools to recognize the ways in which "kill it to save it" continues to empower corporate and other elite interests over the welfare of poor, working and most middle class Americans. We need strong yet accessible political and ideological critique focused on the sometimes subtle rhetoric (but often openly hostile policies) of the rich and powerful. Such contributions continue to be the bone and sinew of this publication and I am proud to introduce the following articles as this issues salvo across the hegemonic bough of corporate American and its cultural minions.

In Jay Corwin's article, the writer reminds us that trying to apply elite and Eurocentric theory to the literature of colonial and post-colonial writers is a treacherous project at best. Corwin suggests that a writer such as Garcia-Marquez cannot be understood adequately through the lens of European theoretical paradigms such as post-structuralism or analytical devices such as "magical realism." Instead, he suggests "critical reconciliation of locus with temporal structures, i.e., the recognition that retrograde time leads to pre-contact Americas rather than to Europe." Only by recognizing the history of indigenous culture and power and its role in mediating colonialism can we get a significant sense of meaning from the works of Garcia Marquez and other similar writers.

Lauren Eastwood's article suggests that civil society (NGOs, social movement organizations, etc.) play a crucial role in negotiating United Nations climate change policy. In part, NGOs often provide important technical assistance and expertise. However, more notable are the ways in which movement organizations and others challenge the elite, "business-as-usual" processes of United Nations policymaking. Such efforts "from below" not only add different perspectives and forms of pressure, but often help determine and define what issues are even considered in 
negotiations. Eastwood's piece argues strongly for the role that organizing and political action play in supplanting the "common sense" around climate change with the "good sense" of environmental, grass roots activists.

Patrick Hogan argues that, contrary to popular opinion, new media is not the panacea for communicative democracy in the $21^{\text {st }}$ Century that some have hoped for. Not only does it propagate many of the same communicative inequalities as traditional media, but in fact exacerbates new inequalities as well. To counter such inequality, Hogan uses recent research on human cognitive and motivational systems to argue that motivational ambivalence, and the power that propagate it, play a huge role in proliferating inequality by stifling deliberation on issues of public concern.

Finally, in Rodica Grigore's analysis of Pessoa's The Book of Disquiet, we are reminded of the importance that disillusionment plays in the recreation of libratory visions. Soares, the fictional author/character in Pessoa's work "soars above his immediate surroundings, and even his corporeal grounding, into the realm of the tangible, the imagination. Dreams, consciousness, imagined realities, make up the existence of the fictional author... since he himself is a dream, an imagined personality that has taken on an actual reality, an instantiation of a poet's selfconsciousness." By occupying this dual space of immediate (real) and mediate (imagined), we visit the power of vision, of dreaming and creating what is not real but could be. Such revolutionary poems or "Freedom Dreams", according to radical historian Robin D.G. Kelley, are the fodder that tangible revolutionary movements are made of. Long live the disillusionment of reality and the reality of freedom dreams! 